\title{
3D FE MODELING OF MULTI-SPAN STONE MASONRY ARCH BRIDGES FOR THE ASSESSMENT OF LOAD CARRYING CAPACITY: THE CASE OF JUSTINIAN'S BRIDGE
}

\author{
VILDAN G. MENTESE $^{1 *}$ AND OGUZ C. CELIK ${ }^{2}$ \\ ${ }^{1}$ M.Sc. Civil Engineer \\ Formerly, M.Sc., Department of Architecture, Istanbul Technical University (ITU) \\ 34810 Istanbul, Turkey \\ e-mail: v.gizem.mentese@gmail.com \\ ${ }^{2}$ Professor of Structural\&Earthquake Engineering \\ Faculty of Architecture, Istanbul Technical University (ITU) \\ Taskisla, 34437 Istanbul, Turkey \\ email: celikoguz@itu.edu.tr
}

Keywords: Justinian's Bridge, Masonry Arch Bridges, Collapse Mechanism, Finite Element Analysis (FEA), Three Dimensional Modeling, Inelastic Behavior.

\begin{abstract}
Substantial part of heritage structures in Turkey is historic masonry arch bridges. To explore modeling issues, a numerical work has been initiated to better understand and preserve/transfer this heritage to the next eras. This paper specifically describes the influence of tensile fracture energy of stone material in determining their true load carrying capacities. A case study is presented to explain the modeling issues. With its historical background, current situation, geometric and material properties, this work focuses on numerical investigation of the historic multi-span stone masonry arch Justinian's (or Sangarius) Bridge located in the city of Sakarya in Turkey over the Sakarya River.
\end{abstract}

Numerical results show that the value of fracture energy in tension significantly affect the load carrying capacity and failure mechanism of multi-span masonry arch bridges. A more realistic nonlinear response has been obtained for an upper value of the tensile fracture energy of the stone masonry. The bridge model collapses by a-three-hinge mechanism occuring at the loaded arch in the upper value of the tensile fracture energy. The most critical loading point of the bridge is determined as the quarter-span.

\section{INTRODUCTION}

Masonry arch bridges are complex and nonlinear structures which consist of barrel vaults, spandrel walls, backfill, infill, piers, flood splitters, and wing walls. Finite element method (FEM) is one of the powerful and most commonly used methods in the investigation of structural behavior and failure mechanisms of such structures. Even though performing a nonlinear static analysis (NSA) by FEM requires additional time and effort, the benefits in understanding the structural behavior of this type of structures are fairly high [1]. 
Masonry is a heterogeneous assemblage that consists of stone and/or brick units and the mortar joints between the units. This complex material displays directional mechanical differences due to the weakness of mortar joints. Existing modeling approaches focus on micro-modeling of the individual component (unit such as stone and mortar) or the macro (composite) modeling of masonry [2]. Based on the desired level of accuracy and allowed computational time, two dimensional (2D) and/or three-dimensional (3D) FE models of masonry arch bridges could be developed by both modeling approaches. The micro modeling should be preferred to understand the collapse mechanism and to observe the hinge formation in the detailed investigation of the masonry bridges. However, the composite modeling based on the homogenization technique [3] is often used due to modeling difficulties of the multispan masonry arch bridges.

There is a wide range of references [4 10] on the nonlinear behavior and possible collapse mechanisms of masonry arch bridges under vertical static loads by using FEM. Each research has made a considerable contribution to the understanding of failure mechanisms of such bridges which have different arch geometry and material properties. Elastic and inelastic mechanical properties of masonry, infill and backfill effect, boundary conditions, modeling approaches, and imposed loads on bridge significantly affect nonlinear response of such structures. To predict the actual behavior of masonry arch bridges, it is essential to integrate nonlinear response of fill material with crushing and cracking behavior of masonry [5 7]. Detailed FE models which consider discontinuities in the joints between voussoirs have generated the reasonable results about the collapse load and corresponding hinge mechanisms This paper presents numerical results from an investigation of the muti-span masonry arch
Justinian's Bridge as a case study. The aim of this work is to search nonlinear structural
behavior of the bridge by the finite element method and to investigate the influence of the
tensile fracture energy of masonry on the collapse mechanisin and load carrying capacity of
the bridge.

Register for free at https//www.scipedia.com to download the version without the watermark

\subsection{Historical significance}

The Justinian's Bridge (also known as the Historical Beşköprü or Sangarius Bridge) was erected to connect Constantinople (today's Istanbul), the capital of the Empire, and the east provinces. The bridge was built in between the years of 553-562 A.D within the 6th century by order of Emperor Justinian (A.D 523-567) of the East-Roman Empire [11]. The bridge takes place over the Sakarya River, in the city of Sakarya in Turkey located on the NorthWest region of Anatolia according to the available registers.

The Justinian's Bridge is a significant sample of bridge heritage that has reached to the present day from the Byzantine Era. There was a triumphal arch until the 19th century in the western entrance of the bridge [11]. This triumphal arch is seen in Jules Lauren's drawing dated 1859 in Fig.1a and in Texier's engraving dated 1838 in Fig.1b. Nowadays, this part has completely vanished (Fig.1b). Today, the bridge is on a dry valley because the wide Sakarya River laid to $3 \mathrm{~km}$ to the East (Fig.2a) and Çark stream, which flows from the nearby Sapanca Lake, flows from a bay of the bridge [15]. The bridge is an unprecedented structure in terms of either its gigantic piers and the apse structures around the bridge (Figs.2a, 2b). 


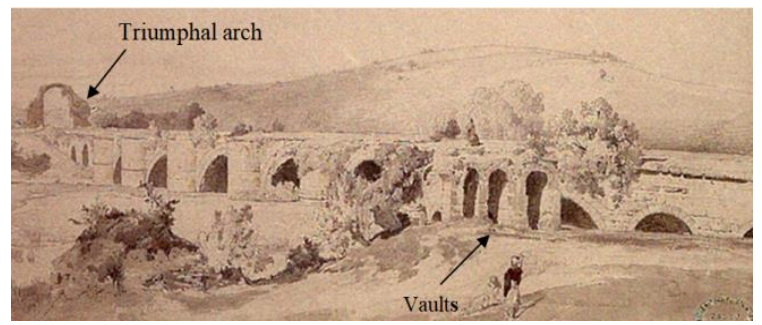

(a)

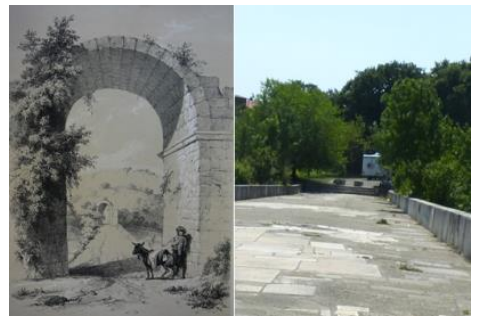

(b)

Figure 1: Justinian's Bridge; (a) painting by Jules Laurens [12], (b) Texier's the lost triumphal arch [13].

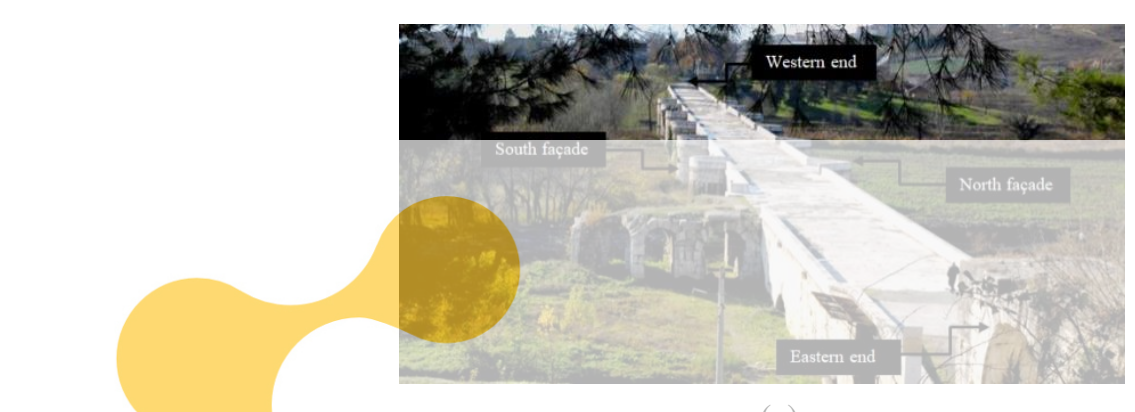

(a)

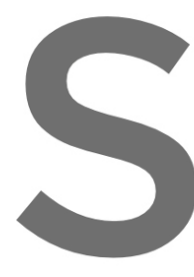

2.2 Past repair intervention

The known last restoration of the bridge Republic of Turkey General Directorate of Highways. Some spandrel walls were replaced with the new ones and the parapets were constructed. However,

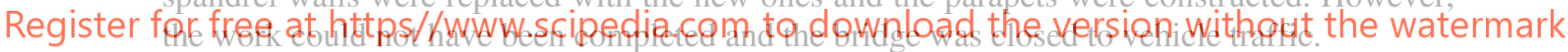

There is no serious misalignment and obliquity in the horizontal line of the walling. A major crack occurred through the intrados of the arch numbered as 4 at an unknown time [15]. Site investigations made in 2016 revealed that there have been some material losses on the components of the bridge such as parapet, slab, and vaults (Fig.3). Besides, a wide shear crack occurred at the South pier of the apse possibly due to past devastating earthquakes (Fig.3c). Note that the bridge under consideration is located in a highly active seismic zone.

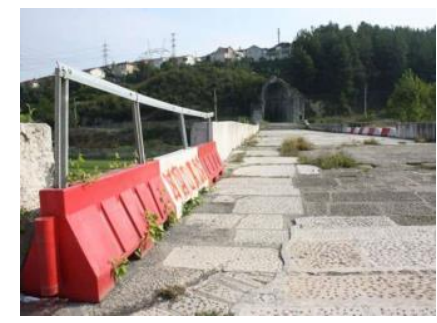

(a)

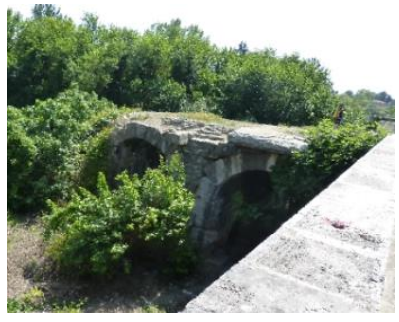

(b)

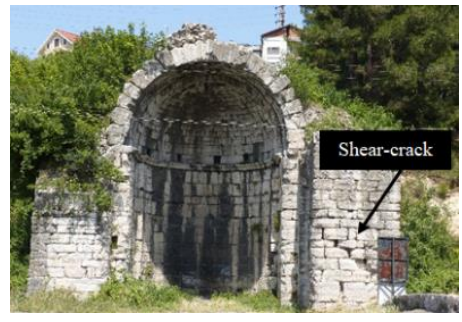

(c)

Figure 3: Current damages [16]; (a) lost parapet part, (b) material loss in vaults, and (c) shear crack in the apse. 
In 2018, the current restoration work was initiated by the Republic of Turkey General Directorate of Highways and the work has continued to the date. The Justinian's Bridge has been inscribed on the United Nations Educational, Scientific and Cultural Organization (UNESCO) World Heritage Tentative List since 2018 [17].

\subsection{Bridge geometry}

The Justinian's Bridge which is a continuous arched masonry bridge has a total length of $429 \mathrm{~m}$ in plan (Fig.4). All arch forms of the bridge are semi-circular in Texier's bridge sketch dated 1838 (Fig.4). The bridge has 12 spans, labeled as A1 to A12 and has 7 piers labeled as P1 to P7. The seven arches, which are main load bearing arches and labeled as A4 A10, are double-layered and the average thicknesses of the first (inner) and second (outer) arches are $1.0 \mathrm{~m}$ and $0.40 \mathrm{~m}$, respectively. The arches labeled as A5, A7, and A8 have maximum spans of $\mathrm{L}=24.5 \mathrm{~m}$. Spans of the arches A4, A6, A9, and A10 vary from $19.5 \mathrm{~m}$ to $24 \mathrm{~m}$. Other arches possess smaller spans ranging from $3 \mathrm{~m}$ to $9 \mathrm{~m}$. The main arches were modeled as spans given in Fig.5b because a small part of the bridge sunk into the existing soil nowadays.
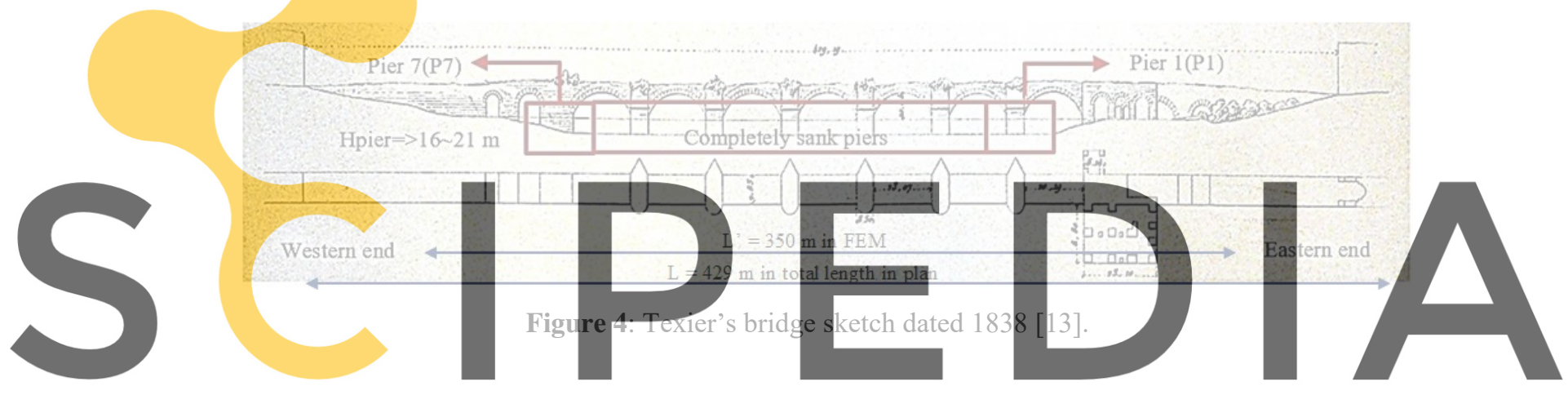

Width of the bridge is $\mathrm{B}=18 \mathrm{~m}$ together with the total pier. However, the clear width of the

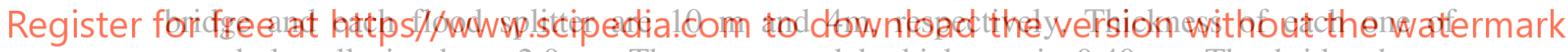
spandrel walls is about $2.0 \mathrm{~m}$. The average slab thickness is $0.40 \mathrm{~m}$. The bridge has a maximum clear height of about $9 \mathrm{~m}$ together with its visible piers. Section of the piers has a pointed shape at the North facade and a semi-circular shaped at the South facade as given in Fig.5a. The thickness and height of the parapets are $0.50 \mathrm{~m}$ and $0.80 \mathrm{~m}$, respectively.

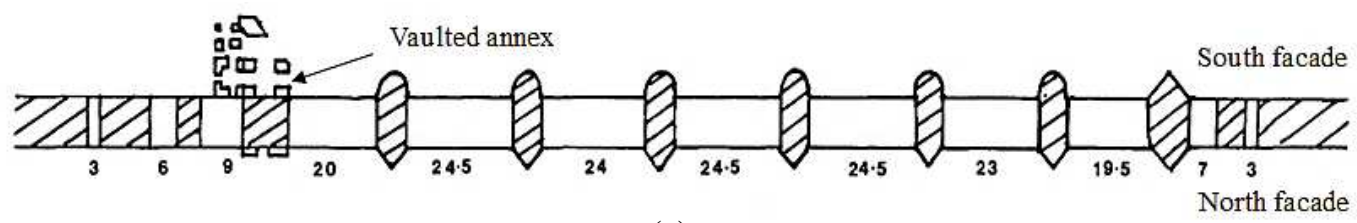

(a)

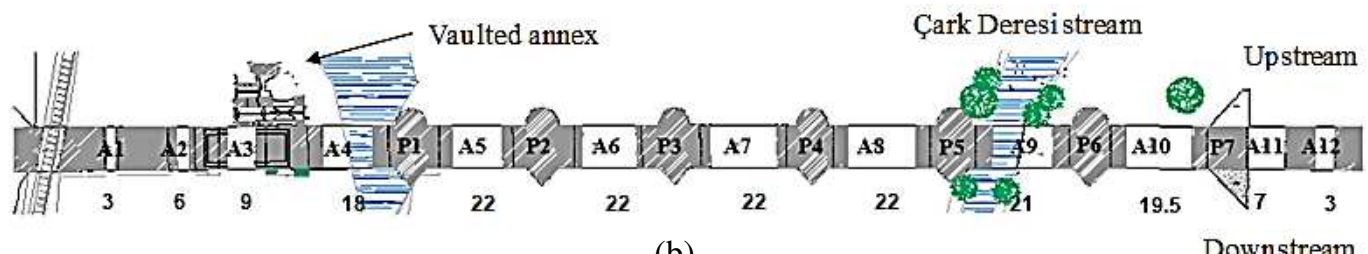

(b)

Figure 5: (a) Plan of the Justinian's Bridge after Texier [11], (b) spans adopted in FEM of the bridge. 


\section{NUMERICAL MODELING}

\subsection{Material property}

Justinian's Bridge was constructed with natural limestone units and brick dust mortar. Rubble stone with mortar was used for backfill (over the arches) and infill (between exterior spandrel walls). The most possible material properties were sought in the well-known references especially focusing on mechanical behavior of masonry bridges since no material tests could have been conducted for the bridge.

Nonlinear behavior of masonry was modeled by adopting the total strain fixed crack model (TSFCM) simulating both compression and tensile behavior of the material, based on the results of a comprehensive study carried out on 3D nonlinear modeling and testing [16]. An exponential softening behavior in tension and parabolic hardening behavior followed by parabolic/exponential softening in compression were chosen. The fill medium was modeled as a cohesive-frictional material by the isotropic Mohr-Coulomb plasticity criterion [7, 8].

Young's modulus (i.e. E modulus) varies from $3000 \mathrm{MPa}$ to $5000 \mathrm{MPa}$ for cut stone masonry with wide joints or substantial rubble masonry [5]. Additionally, the Poisson's ratio $(v)$ was assumed to be the same $(0.20)$ both for main structural elements, which are piers, arches, spandrel walls, and for secondary structural elements such as flood splitters, backfill, infill, slab, and parapet. Table 1 presents the elastic material properties utilized in the numerical implementation of the bridge.
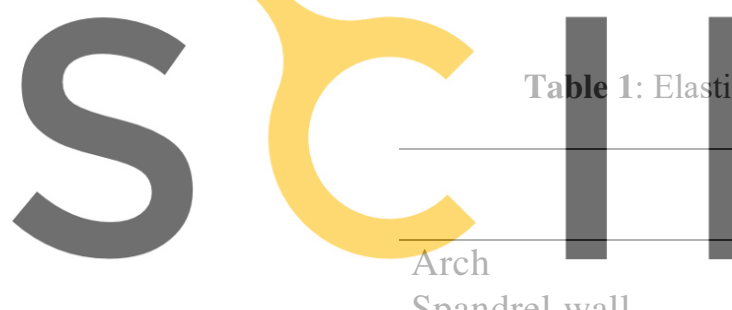

Spandrel wall

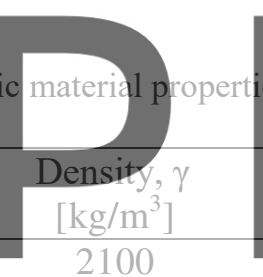

2100

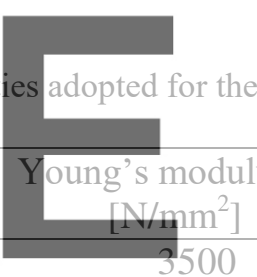

3000

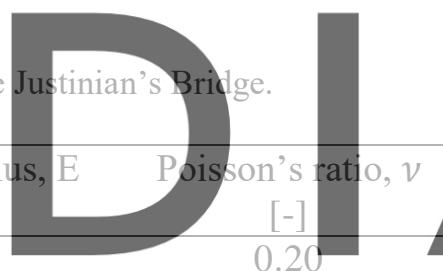

0.20

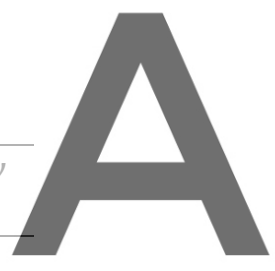

Register for free at ht屯p\$\$fwutw.scipedia.com to downloasdothe version witbout the watermark

\begin{tabular}{lccc} 
Pier & 2100 & 3500 & 0.20 \\
Backfill \& Infill & 1900 & 500 & 0.20 \\
Slab & 1500 & 1000 & 0.20 \\
\hline
\end{tabular}

A recommended value of $8 \mathrm{~N} / \mathrm{mm}^{2}$ was considered for the compressive strength of the masonry material frequently seen in such ancient structures [5]. In the condition that compressive strength of masonry is lower than $12 \mathrm{~N} / \mathrm{mm}^{2}$, the ductility factor for compression is recommended to be $1.6 \mathrm{~mm}$ [18]. The fracture energy in compression was calculated as $12.8 \mathrm{~N} / \mathrm{mm}$ for the compressive strength of $8 \mathrm{~N} / \mathrm{mm}^{2}$ and for the ductility index of $1.6 \mathrm{~mm}$. A numerical value of $0.20 \mathrm{~N} / \mathrm{mm}^{2}$ is adopted for tensile strength of overall masonry [16]. The ductility index for tension, which is the ratio between tensile fracture energy and tensile strength, is recommended to be $0.029 \mathrm{~mm}$ for stone material [18]. In this study, this value was calculated to be $0.01 \mathrm{~N} / \mathrm{mm}$ and was considered as a lower value of tensile fracture energy. However, an average value of $0.10 \mathrm{~N} / \mathrm{mm}$ was adopted for the upper bound of this parameter $[1,7]$. The plasticity parameters of the fill material were chosen based on a comparison and discussion of the information given in the current literature [7, 10, 23]. Inelastic properties of the masonry and the fill material are presented in Table 2. 
Table 2: Inelastic material properties adopted for Justinian's Bridge.

\begin{tabular}{llll}
\hline Masonry material & & & \\
$\mathrm{f}_{\mathrm{t}}$ & 0.20 & {$\left[\mathrm{~N} / \mathrm{mm}^{2}\right]$} & Tensile strength \\
$\mathrm{Gf}^{\mathrm{I}}$ : Lower value & 0.01 & {$[\mathrm{~N} / \mathrm{mm}]$} & Tensile fracture energy \\
$\mathrm{Gf}^{\mathrm{I}}$ : Upper value & 0.10 & {$[\mathrm{~N} / \mathrm{mm}]$} & Tensile fracture energy \\
$\mathrm{f}_{\mathrm{c}}$ & 8.00 & {$\left[\mathrm{~N} / \mathrm{mm}^{2}\right]$} & Compressive strength \\
$\mathrm{Gf}_{\mathrm{c}}$ & 12.8 & {$[\mathrm{~N} / \mathrm{mm}]$} & Compressive fracture energy \\
\hline Backfill \& Infill & & & \\
$\mathrm{c}$ & 0.05 & {$\left[\mathrm{~N} / \mathrm{mm}^{2}\right]$} & Cohesion \\
$\varphi$ & 20 & {$\left[{ }^{\circ}\right]$} & Friction angle \\
$\psi$ & 5 & {$\left[{ }^{\circ}\right]$} & Dilatancy angle \\
\hline
\end{tabular}

\subsection{Three-dimensional (3D) finite element modeling (FEM)}

A 3D FE model of the bridge was generated in DIANA FEA software [19] using isotropic solid elements, making the use of homogenization technique [3]. All components of the bridge, which are the piers, the inner and outer arches, the spandrel walls, the fill material, the slab and the parapets were individually modeled in the macro-modeling strategy as composite [2]. The FE model of the bridge is shown in Figs.6, 7. The bridge was modeled with a total 39863 solid mesh elements which are eight-noded brick elements used for each component and six-noded wedge elements used throughout the arch ring due to the bridge geometry. It

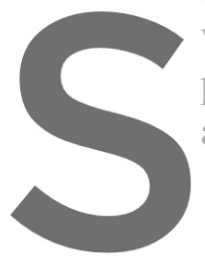
was assumed that the $\mathbf{p}$ parts of piers and side axial motion was restrained in alla
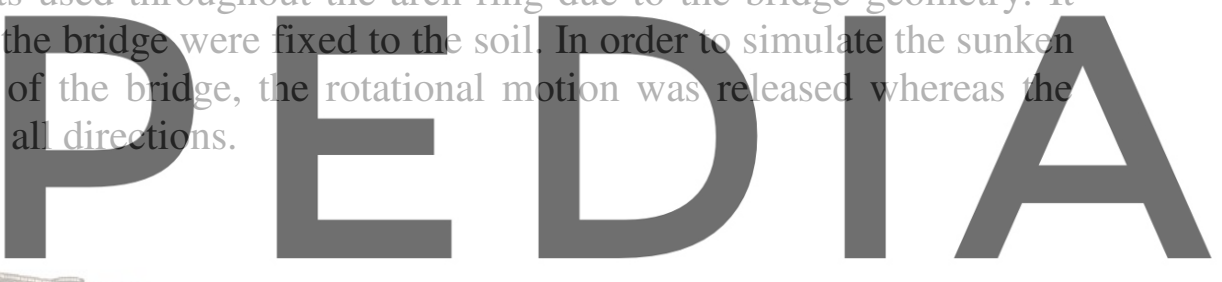

Register for free at https//www.scipedia.com to download the version without the watermark

Figure 6: The Justinian's bridge - finite element model.

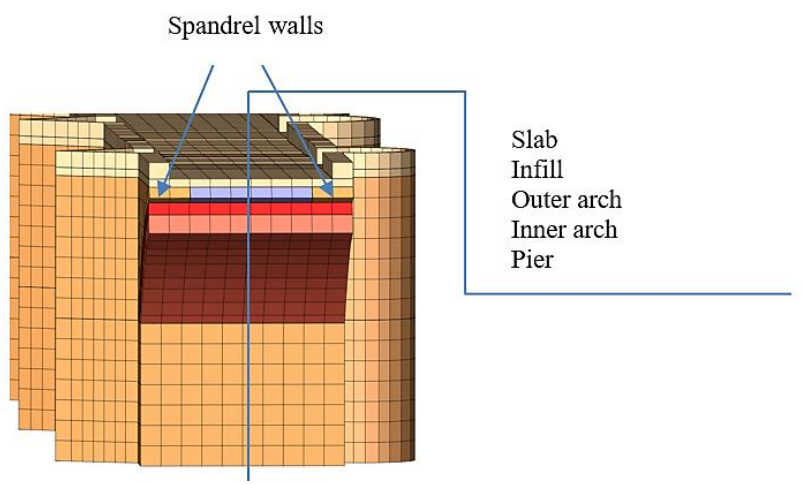

Figure 7: Cross-section view of a typical span of the bridge. 


\subsection{Load cases}

In order to assess the failure mechanism and the critical loading position, the bridge was loaded at three positions of the arch numbered A8 which has the largest span that the maximum displacements and stresses obtained in the linear elastic analyses [20]. Self-weight of the bridge was applied as automatically by the software. Subsequently, the live loads were applied in increments of $200 \mathrm{kN}$ in the vertical direction [21]. The uniformly distributed load was applied to the road surface throughout the full width between the parapets. The loading was then carried out at the quarter (1/4L), one third (1/3L), and middle-span (crown, 1/2L) of the span, respectively as shown in Fig.8.

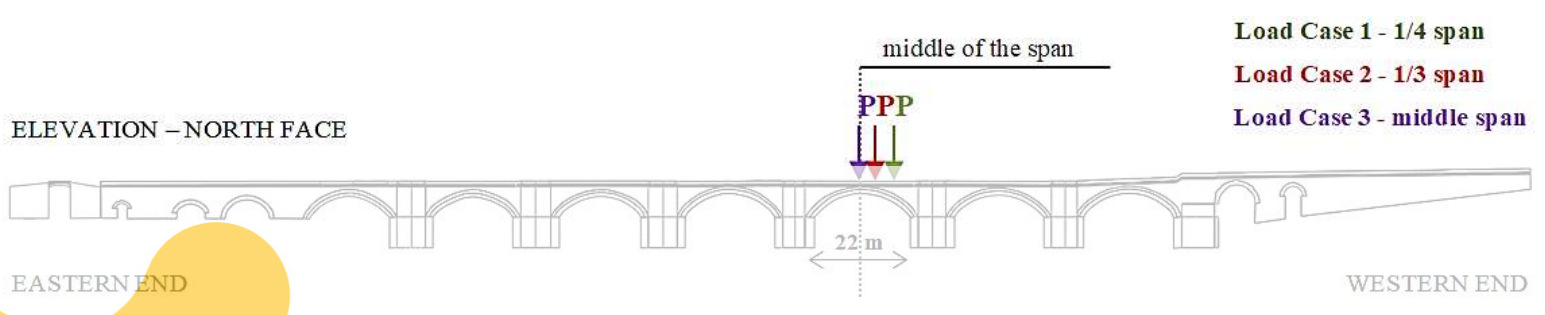

Figure 8: Load cases.

3.4 Nonlinear analysis procedures

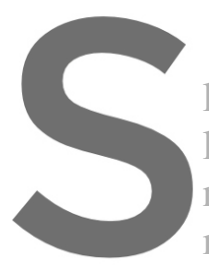

Self-weight of the b live loads up to failure loading was controlled norms should be satisfied to ether in the ocnve masonry [19]. In each step of the incremental ridge was applied first, followed by the application of the in
for each load gase. In the numerical implementation, the incese at
with force, elisplacement and residual norms because at
fied to gether in the convergence criterion for softening b
step of the incremental loading, the iterations were perform incremental
at least thrce
behavior of
med with the modified Newton-Raphson method by integrating the line search method in DIANA [19].

Register for free at https//www, scipedia.com to download the version without the watermark

\subsection{Influence of tensile fracture energy $G f^{1}$}

A series of analysis was carried out for lower and upper values of fracture energy in tension to evaluate the collapse mechanism of the bridge for each load case. The vertical loadvertical deflection curves obtained from the nonlinear static analyses (NSAs) of the bridge are given in Fig.9. Each deflection was monitored after obtaining an equilibrium state in each step of incremental loading. Additionally, upper limit loads are calculated via RING 3.1 [22] and depicted in Figure 9 as well, revealing that the maximum vertical load values obtained from the macro-modeling are close to the ones obtained from the simplified limit analysis.

The numerical results obtained for each load case showed that a lower value of tensile fracture energy cause a weakly nonlinear failure of the bridge. Note that similar results have been reported in other related previous works [7, 16, 23]. The most critical loading position was obtained in the case of middle-span loading for lower value of tensile fracture energy. The failure mechanism occurred by the formation of one-hinge under the middle-span loading of the bridge is given Fig.10 with the presentation of maximum principal stresses. The failure mechanism is relevant around the key stone. 


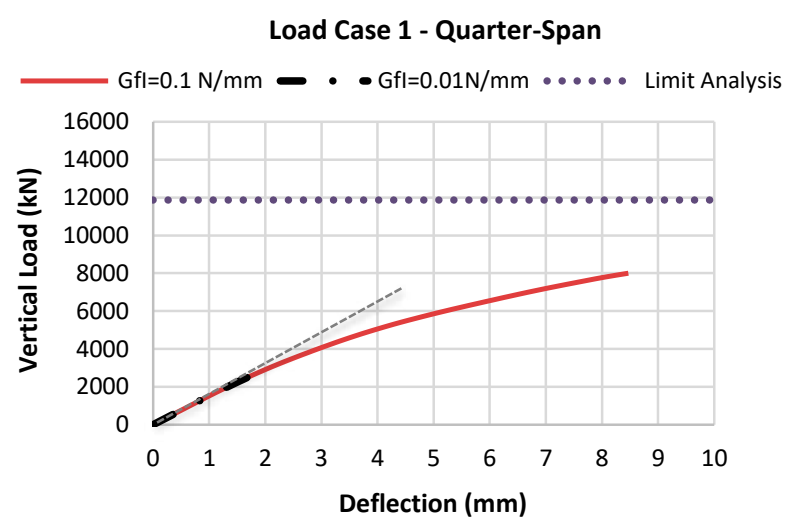

(a)

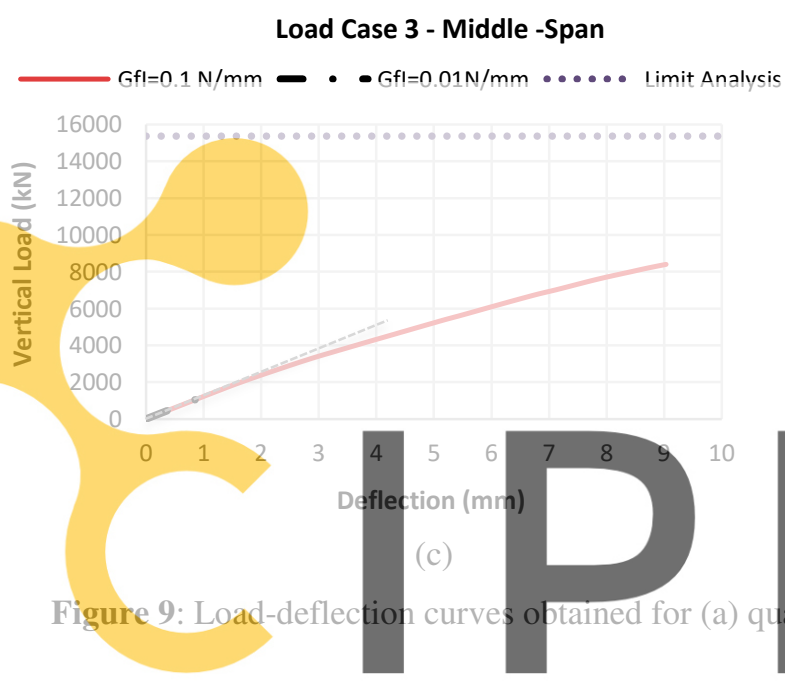

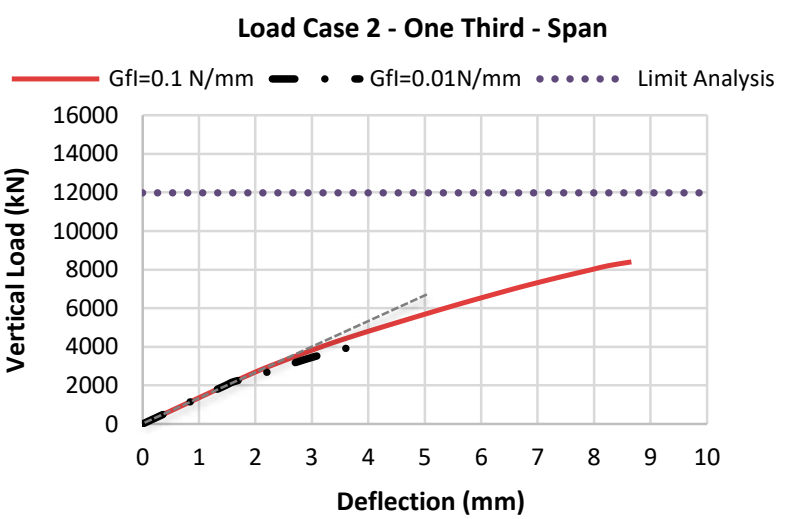

(b)

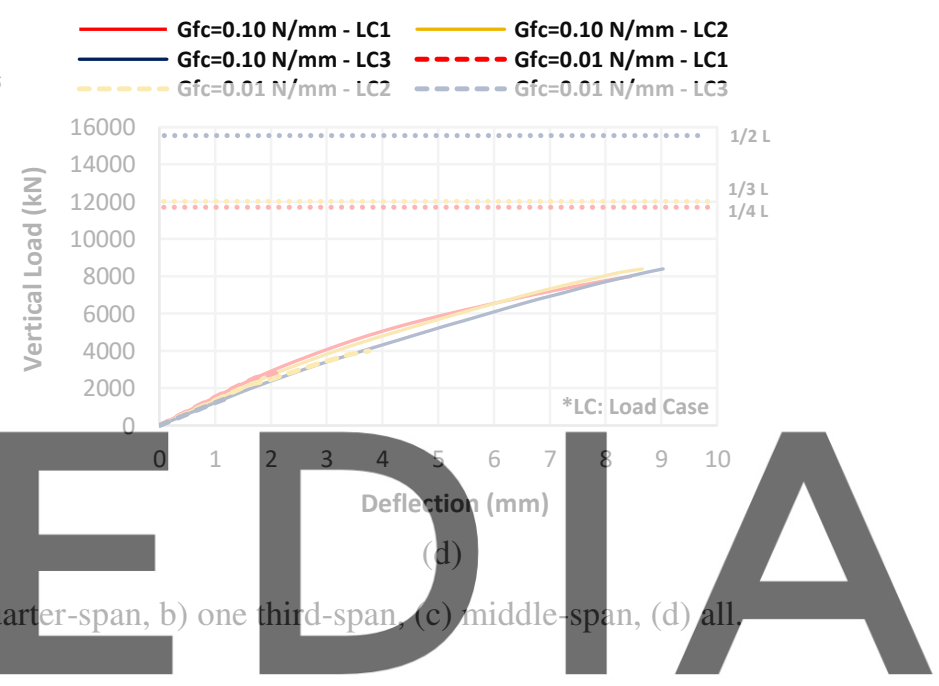

Register for free at https//www.scipedia.com to download the version without the watermark

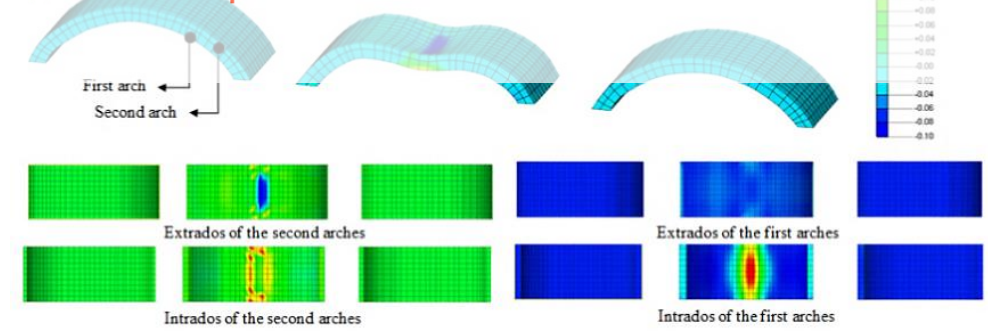

Figure 10: Failure mechanism obtained from the 'middle-span' loading performed for $\mathrm{Gf}$ ' $=0.01 \mathrm{~N} / \mathrm{mm}$ with the presentation of maximum principal stresses (Scale: $-0.10 /+0.22 \mathrm{~N} / \mathrm{mm}^{2}$ ).

For the upper value of tensile fracture energy, the bridge showed a strongly nonlinear behavior and collapsed resulting in larger vertical deflections at a higher load. Note that this is an expected failure type for such structures. The failure loads obtained from the nonlinear static and limit analyses are represented in Table 3. Increasing the value of the fracture energy by 10 times causes 65,55 , and 83 percent increases in the load carrying capacity of the bridge for the loading cases of $1 / 4,1 / 3$, and $1 / 2$ of the span, respectively. 
Table 3: Failure loads obtained for both fracture enegy values in tension.

\begin{tabular}{lcccc}
\hline \multirow{2}{*}{ Load Position } & \multicolumn{2}{c}{ Failure Load $(\mathrm{kN})$} & \multirow{2}{*}{ Difference (\%) } & \multirow{2}{*}{ Limit Analysis } \\
& $\mathrm{Gf}^{\mathrm{I}}=0.01 \mathrm{~N} / \mathrm{mm}$ & $\mathrm{Gf}^{\mathrm{I}}=0.10 \mathrm{~N} / \mathrm{mm}$ & 65 & 11865 \\
Quarter-span & 2800 & 8000 & 55 & 11978 \\
One third-span & 3800 & 8400 & 83 & 15368 \\
Middle-span & 1400 & 8400 & 853 \\
\hline
\end{tabular}

\subsection{Comparison of NSA results for $\mathrm{Gf}^{\mathrm{I}}=0.10 \mathrm{~N} / \mathrm{mm}$}

Nonlinear responses obtained for the upper value of tensile fracture energy are represented in Table 4 for the three load cases. In each loading position, the bridge showed linear behavior up to one third of the ultimate load (Fig.9) and afterwards collapsed by the generation of 3 hinge mechanism. Fig.11 illustrates the obtained failure mechanisms and the corresponding plastic hinge formations under different load cases.

\section{Table 4: Nonlinear responses obtained for $\mathrm{Gf}^{\mathrm{I}}=0.10 \mathrm{~N} / \mathrm{mm}$.}
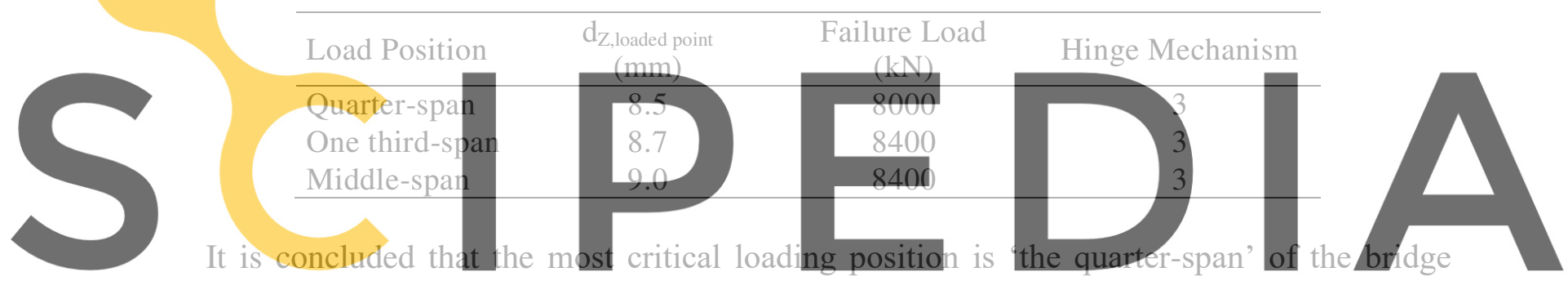

because the lower load carrying capacity was obtained at failure of the bridge. 3D failure

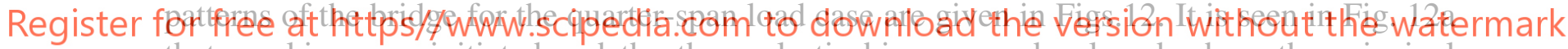
that cracking was initiated and the three plastic hinges are developed where the principal stresses have reached at the tensile strength of the masonry. Plastic hinges occurred at the loaded span, the East and West springings of the arch, respectively. The critical vertical deflection under the load was obtained to be $8.5 \mathrm{~mm}$.

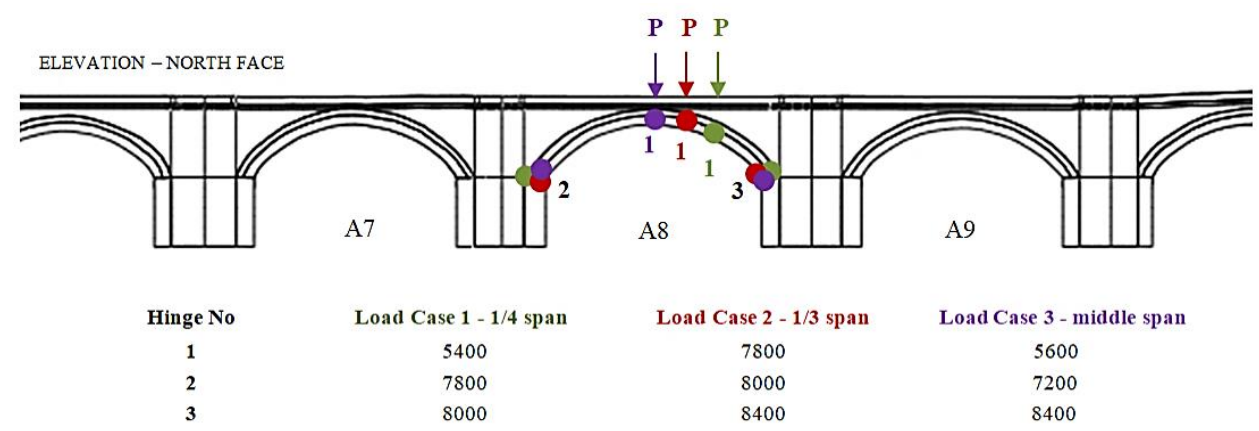

Figure 11: Failure mechanisms for (a) the quarter-span, (b) the one third-span, (c) the middle-span. 

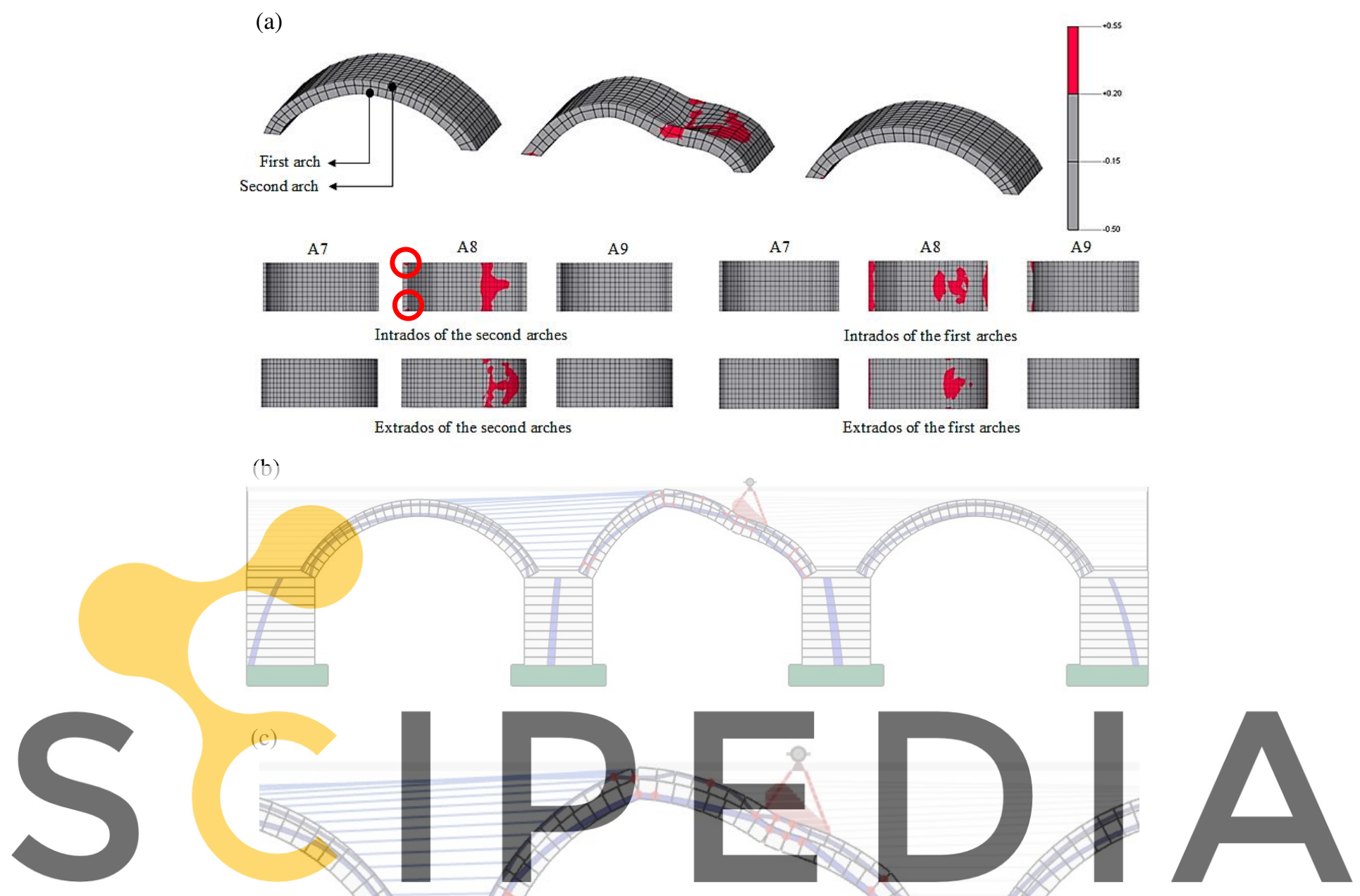

Register for free at https//www.scipedia.com to download the version without the watermark
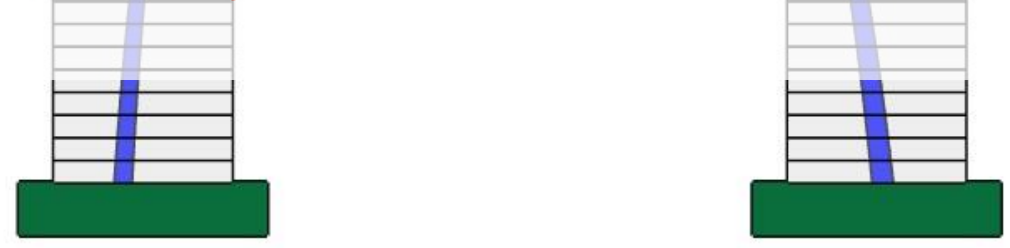

Figure 12: Failure mechanism obtained from the most critical loading position 'quarter-span': (a) finite element model with the presentation of maximum principal stresses for $\mathrm{Gf}^{\mathrm{I}}=0.10 \mathrm{~N} / \mathrm{mm}$ (Scale: $-0.50 /+0.55 \mathrm{~N} / \mathrm{mm}^{2}$ ), (b) rigid block limit analysis model, (c) close-up view of hinge mechanism in rigid block limit analysis model.

\section{CONCLUSIONS}

The existing Justinian's Bridge, located in the city of Sakarya in Turkey, has been investigated to assess the possible collapse mechanism and corresponding load capacity. A 3D structural model for the bridge was developed for this purpose. The bridge was loaded at the quarter, one third, and middle-span of the arch numbered 8 (the largest span). A series of nonlinear static FE analyses were performed for the selected lower and upper values of tensile fracture energy of the stone material. 
Numerical results show that the value of tensile fracture energy considered for masonry material significantly affects the load carrying capacity and collapse mechanism of Justinian's Bridge. In an upper value of $0.10 \mathrm{~N} / \mathrm{mm}$ of tensile fracture energy, the bridge behaves strongly nonlinear and failed by generating the hinge mechanism occurring in the loaded arch for all of the assumed three load cases. Note that no visible damage occurred in both arches adjacent to the collapsed arch. The most critical loading position for the Justinian's Bridge under incremental static loads was obtained at the quarter-span of the loaded arch. The results of rigid block limit analysis carried out for the bridge sufficiently close to the results of nonlinear static analysis. Limit analysis calculations show that the most critical loading position again occurred at the quarter span of the bridge. This significant result confirms the widely accepted testing procedure followed in many research [24, 25].

As a result of the nonlinear finite element analyses, under elastic conditions, the allowable vertical load for the bridge was obtained to be $2400 \mathrm{kN}$ (30\% of the ultimate load) for the upper value of tensile fracture energy. Ultimate load capacity of the bridge was found to be $8000 \mathrm{kN}$ in which the bridge collapsed by the formation of three plastic hinges. It seems that the plastic hinges occurred at the quarter-span, the east, and west springings where the maximum principal stresses have exceeded the existing tensile strength of masonry.

It is concluded that increasing the value of the fracture energy causes an increase in load carrying capacity of such masonry bridges. Finally, in future works, the influence of greater values of tensile fracture energy and the relation between the tensile strength and tensile fracture energy on the load carrying capacity of masonry arch bridges could be investigated by performing sensitivity analyses.

Acknowledgements. This work has been carried out with the financial support from the Scientific and Technological Research Council of Turkey (TUBITAK) under the assigned project number of 114M305.

\section{REFERENCES}

[1] Lourenço, P.B. Analysis of Historical Constructions from Thrust-lines to Advanced Simulations, In P.B. Lourenço and P. Roca (Eds.): Historical Constructions: Possibilities of Numerical and Experimental Techniques, Proceedings of the Third International Seminar (2001).

[2] Lourenço, P.B. Computational Strategies for Masonry Structures. Ph.D Thesis, University of Minho, Braga, Portugal: PhD dissertation (1996).

[3] Lourenço, P.B., Milani, G., Tralli, A., and Zucchini, A. Analysis of masonry structures: review of and recent trends in homogenization techniques. Canadian Journal of Civil Engineering (2007) 34:1443-1457.

[4] Cavicchi, A., and Gambarotta, L. Two-dimensional finite element upper bound limit analysis of masonry bridges. Computers and Structures (2006), 84: 2316-2328.

[5] Fanning, P.J., Boothby, T.E. Three-dimensional modeling and full-scale testing of stone arch bridges. Computers and Structures (2001) 79: 2645-2662.

[6] Frunzio, G., Monaco, M. and Gesualdo, A. 3D F.E.M Analysis of a Roman Arch Bridge. In P.B. Lourenço and P. Roca (Eds.): Historical Constructions: Possibilities of Numerical and Experimental Techniques, Proceedings of the Third International Seminar (2001), pp.591-598. 
[7] Conde, B., Ramos, L. F., Oliveira, D. V., Riveiro, B., and Solla, M. Structural assessment of masonry arch bridges by combination of non-destructive testing tecniques and three-dimensional numerical modeling: Application to Vilanova bridge. Engineering Structures (2017) 148: 621-638.

[8] Milani, G., and Lourenço, P.B. 3D non-linear behavior of masonry arch bridges. Computer and Structures (2012) 110-111: 133-150.

[9] Costa, C., Arede, A., Morais, M., and Anibal, A. Detailed FE and DE modeling of stone masonry arch bridges for the assessment of load-carrying capacity. Procedia Engineering (2015) 114: 854-861.

[10] Diaz, J., Romera, L., and Hernandez, S. Non-linear Finite Element Analysis and Limit Analysis Comparison of the Caaveiro Stone Arch Bridge. In C.A. Brebbia (Ed.): Studies, Repairs and Maintenance of Heritage Architecture, WIT Press (2007), pp.556-575.

[11] Whitby, M. Justinian's Bridge over the Sangarius and the date of Procopius'de Aedificiis. The Journal of Hellenic Studies (1985) 105: 129-148.

[12] <http://kantaratlas.blogspot.com.tr/ >, date retrieved 27.05.2018.

[13] <https://en.wikipedia.org/wiki/Sangarius_Bridge>, date retrieved 29.06.2016.

[14] <http://www.sakaryakulturturizm.gov.tr>, date retrieved 29.06.2016.

[15] Ozcan, Z. Tarihi Sangarius Köprüsü'nde hasar belirlenmesi ve güçlendirme önerileri. 3. Köprüler ve Viyadükler Sempozyumu, Istanbul, Turkey, 8-10 Mayıs, 2015.

[16] Mentese, V.G. 3D Nonlinear Modeling and Testing of Historic Stone Masonry Arch Bridges: The Case of Justinian's Bridge. Istanbul Technical University, Istanbul, Turkey: M.Sc. Thesis (2018).

[17] <whc.unesco.org/en/tentativelists/6347/>, date retrieved 02.05.2018.

[18] Angelillo, M., Lourenço, P.B., Milani, G. Masonry Behaviour and Modelling. In M. Angelillo (Ed.): Mechanics of Masonry Structures, Springer (2014), pp.13-27.

[19] TNO DIANA 9.6. Diana Finite Element Analysis. Delft, The Netherlands: 2014.

[20] Mentese, V.G., Gedik, Y.H., Gunes, O., and Korkmaz, K.A. Structural Investigation on Justinianus Bridge in Sakarya city of Turkey. 1st Istanbul Bridge Conference, Istanbul, Turkey, August 8-9, 2016.

[21] Page, J. Load tests to collapse on two arch bridges at Preston, Shropshire and Prestwood, Staffordshire (Report No. 110). UK: The Report of Transport and Road Research Laboratory (TRRL), Department of Transport (1987).

[22] LimitState: RING 3.1. Masonry Arch Analysis Software. Sheffield, the UK: 2014.

[23] Pulatsu, B., Erdogmus, E., and Bretas, E. Parametric study on masonry arches using 2D discrete element modeling. Journal of Architectural Engineering (2018). 24(2).

[24] Page, J. Load Tests to Collapse on Masonry Arch Bridges. In T. Telford and C. Melbourne (Eds.): Arch Bridges, Thomas Telford, UK: London (1995), pp.289-298.

[25] Brencich, A., and De Francesco, U. Assessment of multispan masonry arch bridges. II: Examples and applications. Journal of Bridge Engineering (2004) 9(6): 591-598. 